Charles Olson 
THIS PAGE INTENTIONALLY LEFT BLANK 


\section{Charles Olson}

Call Him Ishmael

BY PAUL CHRISTENSEN

Foreword by George F. Butterick

University of Texas Press, Austin 
To my parents

Due to the lengthy copyright data, an extension of the copyright page is given on page 245 .

Library of Congress Cataloging in Publication Data Christensen, Paul.

Charles Olson, call him Ishmael.

Bibliography: $p$.

Includes index.

I. Olson, Charles, I910-1970-Criticism and interpretation. I. Title.

PS3529.L655Z6I5 8II'.5'4 78-8624

ISBN 0-292-71046-I

Copyright (C) 1975, 1979 by Paul Christensen

All rights reserved

Printed in the United States of America

ISBN 978-0-292-76242-8 (library e-book)

ISBN 978-0-292-76243-5 (individual e-book) 